\title{
Recent non-marine Ostracoda from Jamaica, West Indies
}

\author{
JONATHAN A. HOLMES \\ School of Geography, Kingston University, Penrhyn Road, Kingston upon Thames, Surrey KT1 2EE, UK.
}

\begin{abstract}
Ostracods were sampled qualitatively at 22 sites from 15 waterbodies in the western part of Jamaica and determinations of the water chemistry and habitat characteristics were made at each locality. Most of the ostracods found belong to the Cypridinae, Cypridopsinae, Cyclocypridinae and Darwinulidae. There is a clear distinction between the faunas found in the larger, permanent lakes and the smaller ponds. The latter are subject to large fluctuations in volume and may desiccate either seasonally or interannually. Within the largest lake, Wallywash Great Pond, there is some degree of spatial zonation in the ostracod faunas that appears to be related to water depth and aquatic macrophyte occurrence. The distribution of modern ostracods within Wallywash Great Pond suggests that the late Quaternary faunal sequence from this lake is primarily a function of lake-level changes. J. Micropalaeontol. 16(2): 137-143, October 1997.
\end{abstract}

\section{INTRODUCTION}

Quaternary non-marine ostracods have the potential to provide excellent palaeoenvironmental information (e.g. Holmes, 1992). However, reconstructions are often hampered by the lack of an adequate taxonomy and incomplete ecological data for the species concerned. Work on a 125000 year lake-sediment core from southwestern Jamaica (Holmes, in press) has revealed abundant, well preserved ostracods. In this paper, the modern distribution of non-marine ostracods in Jamaica is described and their potential for palaeoenvironmental reconstruction discussed.

There is little existing information about the non-marine ostracods of Jamaica. Herrick (1887) reported the occurrence of Chlamydotheca unispinosa (Baird, 1862) from the island. Tressler (1956) made collections from bromeliad cups at numerous locations throughout the island and identified two species, Candonopsis anisitsi and Metacypris laesslei (=Elpidium laesslei), from these specialized habitats. Broodbakker (1982, 1983a,b,c,d, 1984a,b,c) studied ostracods collected as part of the Amsterdam expeditions to the West Indies in the 1970s and early 1980s. Despite the wealth of information contained in these reports, only 9 of the 50 localities collected in Jamaica yielded ostracods and none of these were taken from lakes or ponds. Indeed, Broodbakker (1984a) maintained, with regard to Jamaica, that 'The number of stations yielding ostracods ... is not sufficient to allow any conclusions about the ostracod fauna...' (p.38).

With the exception of Broodbakker's work, information on the ostracod fauna of other Caribbean island is also limited. Klie (1933) and Triebel $(1961,1962)$ described ostracods from Aruba, Bonaire and Curaçao, Margalef (1961) from Margarita, van den Bold (1958) from Trinidad and Harrison \& Rankin (1976) from St Vincent. Martens \& Behen (1994) recently produced a checklist of the inland waters of South America and the adjacent islands.

\section{SAMPLING SITES AND METHODS}

Sampling localities were restricted to ponds or lakes marked on the 1:50000 JSD/DOS maps. Sampling was undertaken in August 1990 . At each site, ostracods were sampled qualitatively with a hand net. A range of ecological variables was also measured, including water temperature, $\mathrm{pH}$, dissolved oxygen content, major and trace anions and cations and nutrients, together with information on depth, macrophyte cover, surrounding vegetation, and underlying geology. Summary characteristics of each waterbody are given below and in Table 1 .

The study was confined to the western part of the island which is underlain either by limestone or superficial sediments. The waterbodies sampled fall into three geographical areas (Fig. 1). For most waterbodies, a single sample was collected in shallow water close to the water's edge. More detailed sampling was undertaken on Wallywash Great Pond (Fig. 2), the largest lake sampled and the one from which the lake-sediment core was taken. Most other sites, however, are not named either formally or otherwise, so informal names, given on the basis of land ownership or geographical location, are used here. Brief details of the sites containing ostracods are given below.

\section{Mt Airy Pond}

A small (area $\approx 0.06 \mathrm{~km}^{2}$ ) permanent pond with common emergent macrophytes, located in a closed, fault-bounded basin. Ostracods were collected in $\sim 20 \mathrm{~cm}$ deep, moderately-clear water with a substrate of fine calcareous mud.

\section{Negril Road Pond}

A small (area $\approx 0.01 \mathrm{~km}^{2}$ ) permanent pond located in a closed fault-bounded basin and with abundant floating green algae on the water surface. Ostracods were collected in $\sim 10 \mathrm{~cm}$ deep, turbid water with a substrate of clayey mud.

\section{Maragh Pond and Norman's Pond}

Two small (area $<0.01 \mathrm{~km}^{2}$ ) ponds at Old Hope Pen located in small, closed depressions. These small ponds probably fluctuate dramatically in volume and may dry out either seasonally or interannually. At the time of sampling, both ponds were overgrown with floating and emergent macrophytes. Ostracods were collected in $<20 \mathrm{~cm}$ deep clear water with a substrate of organic mud.

\section{Old Hope Ponds 1-4}

Four small (area $\approx 0.01 \mathrm{~km}^{2}$ ) ponds amongst many in an area less than $1 \mathrm{~km}$ north of Old Hope village, all of which are located in small closed depressions. These small ponds probably fluctuate dramatically in volume and may dry out either seasonally or interannually. Abundant floating and emergent macrophytes were present at the time of sampling. Ostracods 


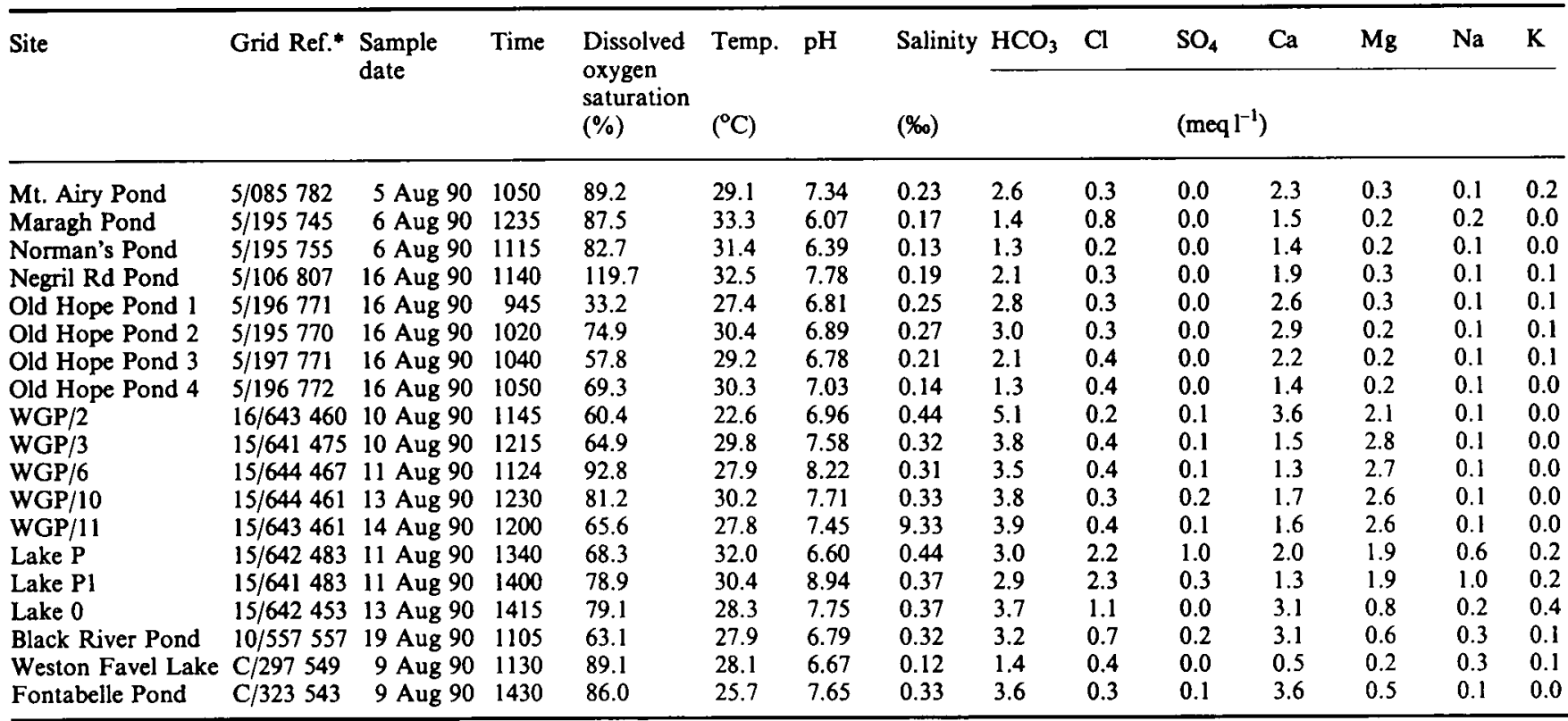

* Grid references with a number prefix refer to 1:50000 JSD/DOS sheets and those with letter prefixes to 1:50000 DOS sheets.

Table 1. Summary of water chemistry data and other ecological variables for the sites sampled

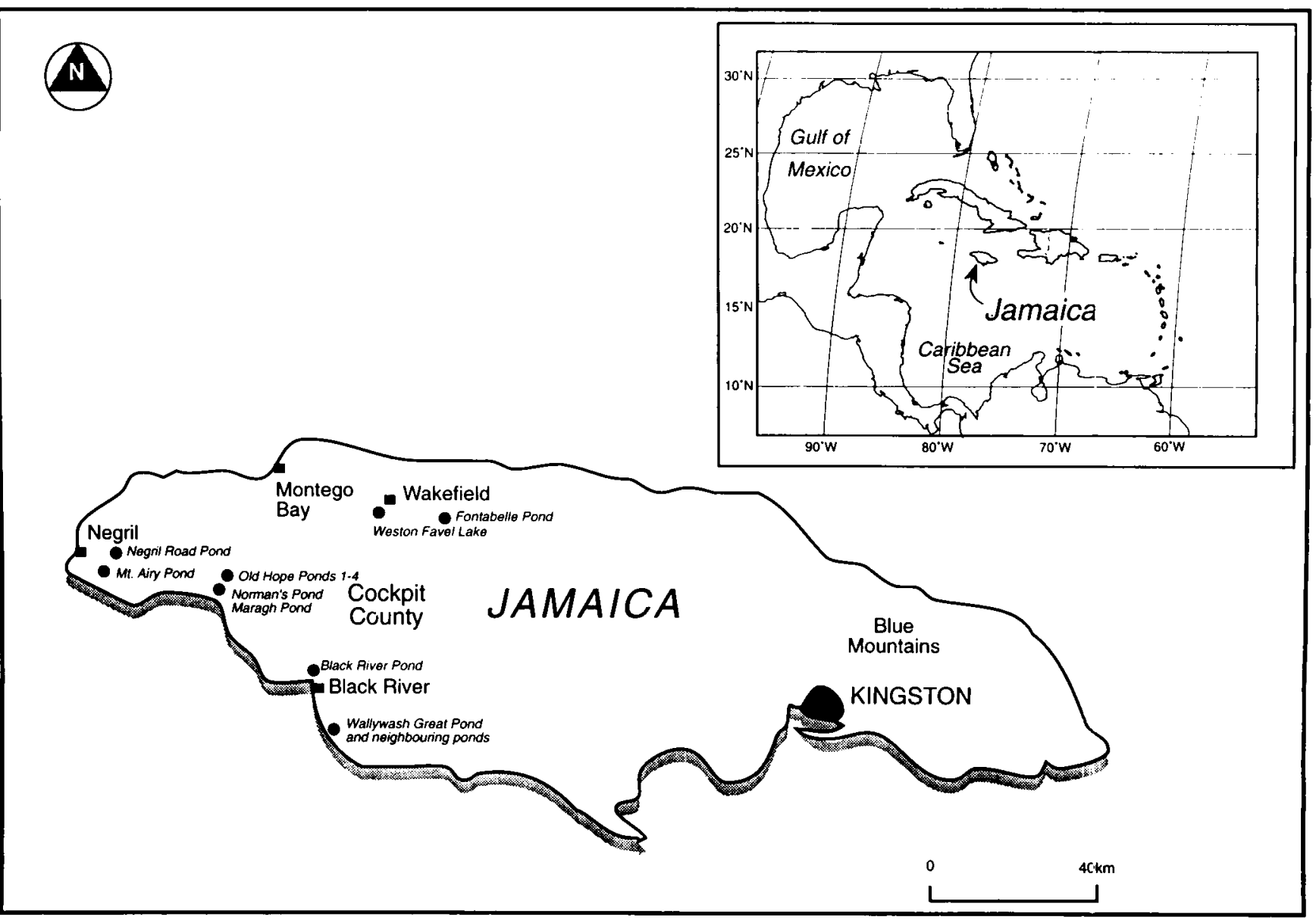

Fig. 1. Location of the sites sampled. 
were collected in fairly turbid water $<20 \mathrm{~cm}$ deep and with a substrate of clayey mud.

\section{Wallywash Great Pond}

The largest natural perennial freshwater lake in Jamaica (area $\approx 0.76 \mathrm{~km}^{2}$, maximum depth of $5 \mathrm{~m}$ ) located in a fault-bounded basin. It is fed by two springs and has a small, hand-dug outlet at the northern end. The lake supports dense emergent, floating and submerged macrophytes. Fish are extremely common in this lake, and the occasional American crocodile (Crocodylus acutus) is also found. In the Great Pond, there are four clearly-defined belts of aquatic vegetation (Street-Perrott et al., 1993). Around the edge of lake, except close to the spring, is a freshwater swamp with Typha, Cyperus and Cladium spp. Further towards the lake is a zone of floating macrophytes that includes Nymphaea and Nymphoides spp. This is followed by dense stands of submerged macrophytes like Potamogeton and Chara spp., the latter found on the deepest parts of the lake floor. Ostracods were collected at selected sites (Fig. 2) which were sampled as part of a wider programme for the analysis of aquatic chemistry.

Sample 1 was collected amongst floating macrophytes in clear water $\sim 1 \mathrm{~m}$ deep, with a substrate of organic mud.

Sample 2 was taken from the mouth of the small cave from which a spring emerges. At the sampling site, the water was $\sim 20 \mathrm{~cm}$ deep and very clear, with a substrate of limestone gravel.

Sample 3 was taken in clear, gently flowing water in the outlet of the lake from amongst emergent macrophytes, with an organic mud substrate.

Sample 10 was taken in clear water $\sim 1 \mathrm{~m}$ deep amongst marginal reed swamp.

Tow 1 (Fig. 2) was undertaken with a zooplankton net which was dragged slowly through the dense stands of Potamogeton sp. to a maximum depth of $\sim 2 \mathrm{~m}$ below the water surface. Time of collection was between 11.00 and $12.30 \mathrm{~h}$.

Tow 2 (Fig. 2) was undertaken with the zooplankton net held above the surface of the submerged macrophyte beds and allowed to sink no more than $0.5 \mathrm{~m}$ below the water surface. Time of collection was between 12.00 and $12.30 \mathrm{~h}$.

\section{Lakes P and P1}

These two waterbodies lie in a network of small (total area $\approx 0.01 \mathrm{~km}^{2}$ ) ponds in the morass to the north of Wallywash Great Pond (Fig. 2). Ostracods were collected in clear water $\sim 20 \mathrm{~cm}$ deep with an organic mud substrate, amongst floating macrophytes. This network of ponds is probably permanent although P1, which is an outlier from the morass, may be ephemeral. Both of these lakes lie within a zone of mixing between fresh and saline groundwaters (UNDP/FAO, 1971) and this accounts for their contrasting chemical composition to Wallywash Great Pond (Table 1).

\section{Lake $\boldsymbol{O}$}

A small (area $\approx 0.01 \mathrm{~km}^{2}$ ) permanent lake located in a closed depression $\sim 1 \mathrm{~km}$ to the south of the southern shore of Wallywash Great Pond. At the time of sampling the edges of the lake were covered with submerged and emergent macrophytes. Ostracods were collected in moderately clear water

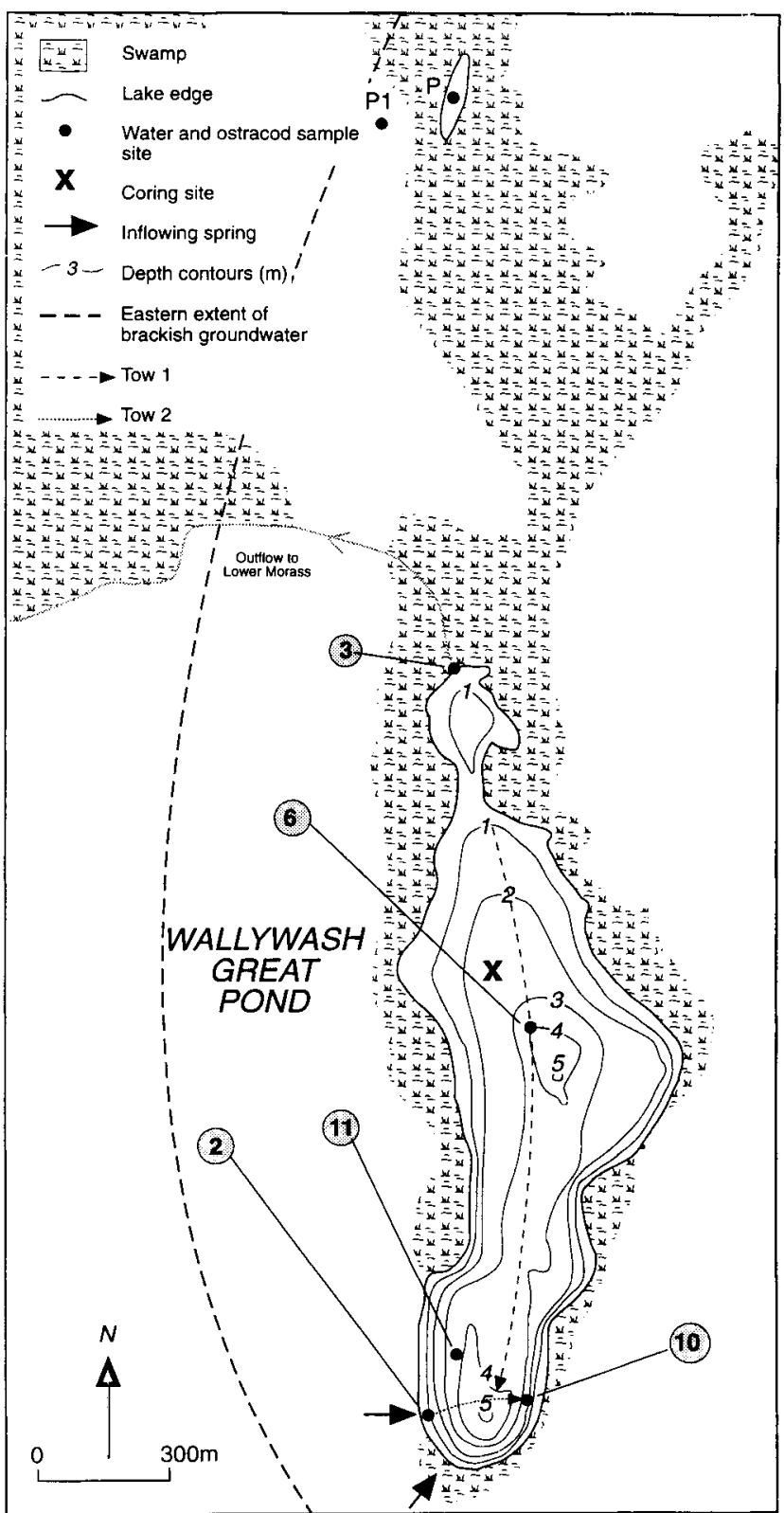

Fig. 2. Map of Wallywash Great Pond showing the location of the sampling sites.

$<20 \mathrm{~cm}$ deep, with a substrate of clayey mud. This lake may also lie within the zone of mixing between fresh and saline groundwater.

\section{Black River Pond}

A small (area $\approx 0.01 \mathrm{~km}^{2}$ ) permanent lake located in a closed depression. The pond was overgrown with emergent and floating macrophytes at the time of sampling. Ostracods were collected in moderately clear water $<20 \mathrm{~cm}$ deep with a substrate of fine organic mud.

\section{Weston Favel Lake}

A small (area $\approx 0.05 \mathrm{~km}^{2}$ ) permanent lake within a closed 
depression in the Queen of Spain's Valley, on the northern margin of the Cockpit Country, an area of cockpit and cone karst. Ostracods were collected in clear water $<20 \mathrm{~cm}$ deep with a substrate of fine organic mud, from amongst floating macrophyte beds.

\section{Fontabelle Pond}

A small (area $\approx 0.05 \mathrm{~km}^{2}$ ) lake within a fault bounded basin which is fed partly by a vauclusian spring (Zans et al., 1962) and which has a small surface outlet. Macrophytes were sparse at the time of sampling. Ostracods were collected in clear water $<50 \mathrm{~cm}$ deep with a substrate of clay.

\section{RESULTS}

Ostracods were found at 22 sites sampled from 15 waterbodies. The following taxa were identified:

Darwinula sp. gr. stevensoni (Brady \& Robertson, 1870)

Darwinula sp. gr. africana (Klie, 1935)

Cytheridella ilosvayi Daday, 1905

Candonopsis sp. indet

Physocypria deformis Klie, 1940

Hemicypris barbadensis Broodbakker, 1983

Hemicypris pyxidata (Moniez, 1892)

Strandesia pistrix Broodbakker, 1983

Strandesia sp. cf. S. vavrai (Müller, 1898)

Stenocypris major (Baird, 1859)

Chlamydotheca deformis caerensis Farkas, 1958

Chlamydotheca unispinosa (Baird, 1862)

Cypris decaryi Gauthier, 1933

Cypris subglobosa Sowerby, 1840

Diaphanocypris meridana (Furtos, 1936)

Cypretta brevisaepta Furtos, 1934

Cypridopsis viduella Sars, 1895

Cypridopsine sp. indet. $1 \& 2$

The distribution of ostracods is shown in Fig. 3. Of the 19 taxa encountered, 16 were identified to specific level or species group; the remaining three included one Candonopsis $\mathrm{sp}$. and at least two species belonging to undetermined genera of the subfamily Cypridopsinae (K. Martens, pers. comm. 1994). Unless otherwise noted, the faunas represent assemblages that were living at, or close to, the time of collection. This was confirmed by the presence of appendages.

\section{DISCUSSION}

\section{General patterns of ostracod distribution}

Broodbakker (1983c) found that the main ostracod groups living in the West Indies belong to the subfamilies Cypridinae, Cypridopsinae and Cyclocypridinae and that the Limnocytheridae and Darwinulidae are poorly represented. The results of the present study generally support Broodbakker's results. However, one representative of the Limnocytheridae, Cytheridella ilosvayi, was found in Jamaica; the Candonidae were found to be rare, although Darwinula spp. were quite common, especially in the larger, permanent, waterbodies.

The genus Diaphanocypris has, to date, been found solely in the Neotropics. Two of the genera found in this study, namely Chlamydotheca and Cytheridella are commonly found in the
Neotropics although the former also occurs in Australasia, the latter in Africa: others, including Hemicypris, Cypretta, Stenocypris and Strandesia are found throughout the tropics and subtropics. The remaining groups are cosmopolitan in distribution. Three of the species encountered are either extremely rare, or have not previously been found, in the Neotropical region and are illustrated in Fig. 4; these are Physocypria deformis Klie, 1940, Hemicypris pyxidata (Moniez, 1892) and Cypridopsis viduella Sars, 1895.

Within the study area as a whole, there is a distinction between the ostracod faunas found in the larger permanent lakes, and those from smaller lakes and ponds which, if not temporary, are shallow and subject to dramatic fluctuations in depth and which desiccate periodically at the margins.

The smallest waterbodies, including Maragh Pond, Norman's Pond, and the Old Hope Ponds, are dominated by genera that are adapted to temporary habitats, such as Cypris, Hemicypris and Chlamydotheca. However, there are rare elements within the faunas that suggest more permanent, open-water conditions. Although these waterbodies may not be truly temporary, they undoubtedly fluctuate in volume, producing temporary habitats along the margins.

The larger waterbodies that include Mt Airy Pond, Negril Road Pond, Black River Pond and lake $\mathrm{O}$ are also dominated by Cypris, Hemicypris and Chlamydotheca. The ostracod samples were generally collected in the shallow waters along the margins of these waterbodies, which are subject to wide variations in water level.

Wallywash Great Pond is dominated by males and females of Cypretta brevisaepta, although other species are found in specific habitats within the lake, as discussed below. Weston Favel lake, the other large waterbody sampled, has a similar fauna to the Great Pond.

Distribution of ostracods in Wallywash Great Pond and neighbouring waterbodies

Within Wallywash Great Pond, the deeper, open-waters were dominated by $C$. brevisaepta, which is an active swimmer. The greater abundance of ostracods in tow 1 compared to tow 2 suggests that $C$. brevisaepta prefers to swim high in the water column, but amongst the stands of Potamogeton sp. rather than close to the surface in fully open water. This may be a response to predation by the abundant fish fauna in the truly open-water environment. Darwinula gr. africana was also common in tow 1. Since this species cannot swim, it must have been collected from the substrate from the initial part of the tow which was undertaken in shallower water, close to the lake margin.

Towards the edge of the lake, at the boundary between the reed swamp and open water, the fauna was more diverse, being dominated by $C$. brevisaepta and both males and females of Cytheridella ilosvayi. The latter is a benthonic, non-swimming ostracod that was found crawling amongst the calcareous organic mud substrate. Other non-swimming species, including Candonopsis sp. and D. gr. stevensoni, were also found; both of these species seem to like crawling over organic-rich substrates. Several specimens of $H$. pyxidata and Chlamydotheca deformis caerensis present in this sample may have been derived from the shallow water environment nearer the edge of the lake. Within the reed swamp proper, Strandesia pistrix and D. gr. africana are 


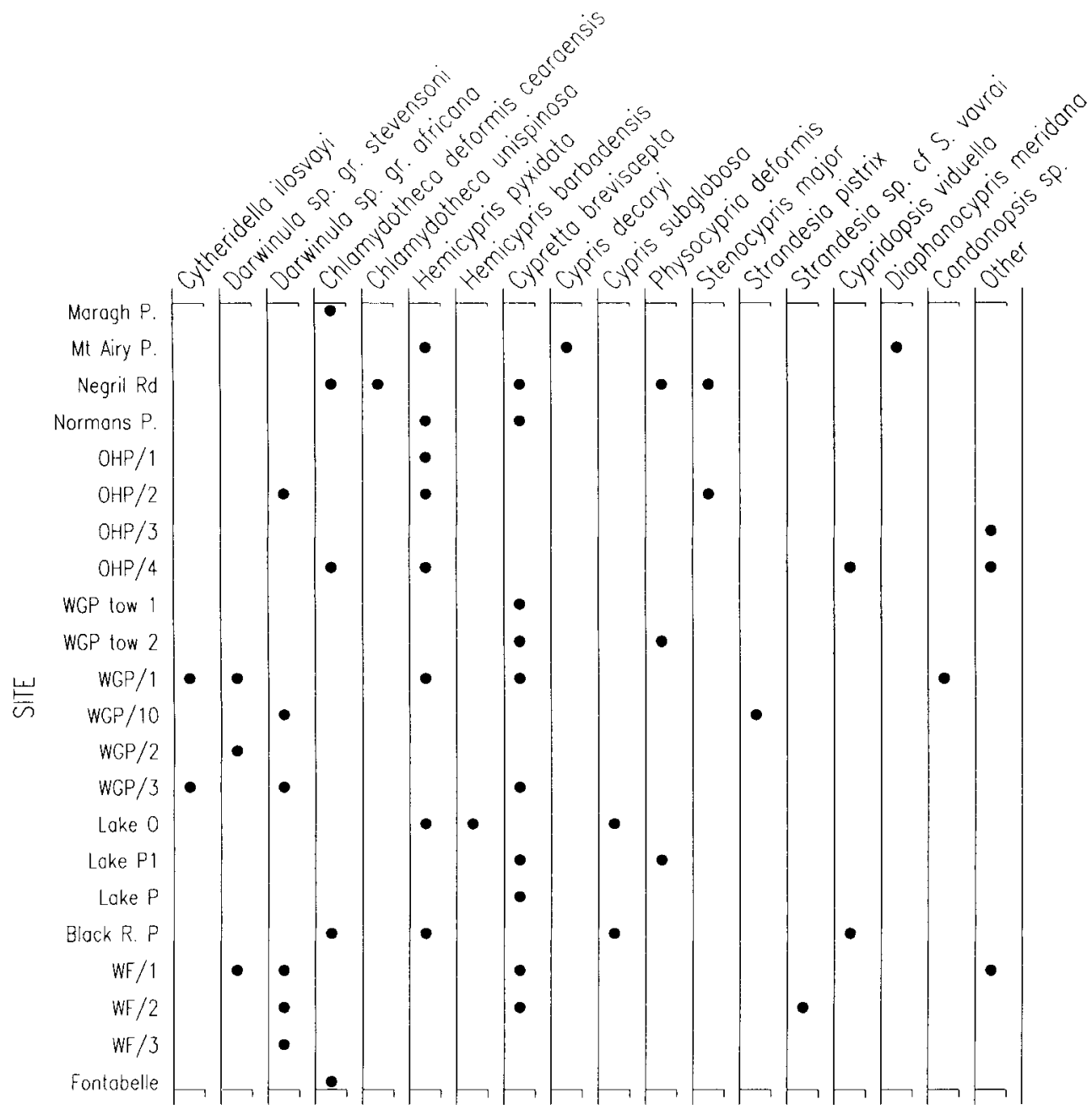

Fig. 3. Distribution of modern ostracods in the study area.

the most common species. Members of the genus Strandesia are typically good swimmers, but are generally associated with dense aquatic macrophytes.

The spring site is dominated by $D$. gr. stevensoni, although other species such as $C$. brevisaepta, $C$. ilosvayi and Candonopsis $\mathrm{sp}$. occur rarely. The spring emerges from a small limestone cave and the sample was taken in the gravel substrate in its mouth. Thus, the sample does not represent a spring fauna in the strict sense, rather that of a cool, flowing stream with a gravel substrate. Broodbakker (1984a) has also reported Darwinula sp. from spring habitats within the Caribbean islands.

The outlet of the lake is dominated by C. brevisaepta although other species, such as Cytheridella ilosvayi and Darwinula gr. africana are also found. Although the lake is shallow at this site $(<30 \mathrm{~cm}$ deep), the open-water conditions with occasional macrophytes are obviously favourable habitats for $C$. brevisaepta.

C. brevisaepta is also the dominant ostracod in lakes P and P1. Samples from these lakes were taken in open water from amongst submerged macrophytes, the favoured habitat for this species in Wallywash Great Pond. The presence of $C$. brevisaepta in lakes $\mathbf{P}$ and $\mathbf{P} 1$ suggests that the species is tolerant of at least slight variations in the salinity and ionic composition of its host water.

Implications of the modern faunal assemblages for the Quaternary palaeoecology of Wallywash Great Pond

Detailed work on the ostracod palaeoecology of Wallywash Great Pond is described by Holmes (in press). This work is based on ostracods extracted from a $9.23 \mathrm{~m}$ core taken from the north-central part of the lake (Core WGP/2) (Fig. 2). The core consists of pure marls, indicating deep, open-water conditions, organic marls and muds formed under dense stands of submerged and floating macrophytes, and organic mud and peat which indicate reed swamp. Earthy calcareous muds formed when the lake was either dry or ephemeral. Sedimentological and geochemical data strongly suggest that the major facies changes within the core represent lake-level variations that were responses to late Quaternary changes in climate and sealevel (Street-Perrott et al., 1993; Holmes et al., 1995). 


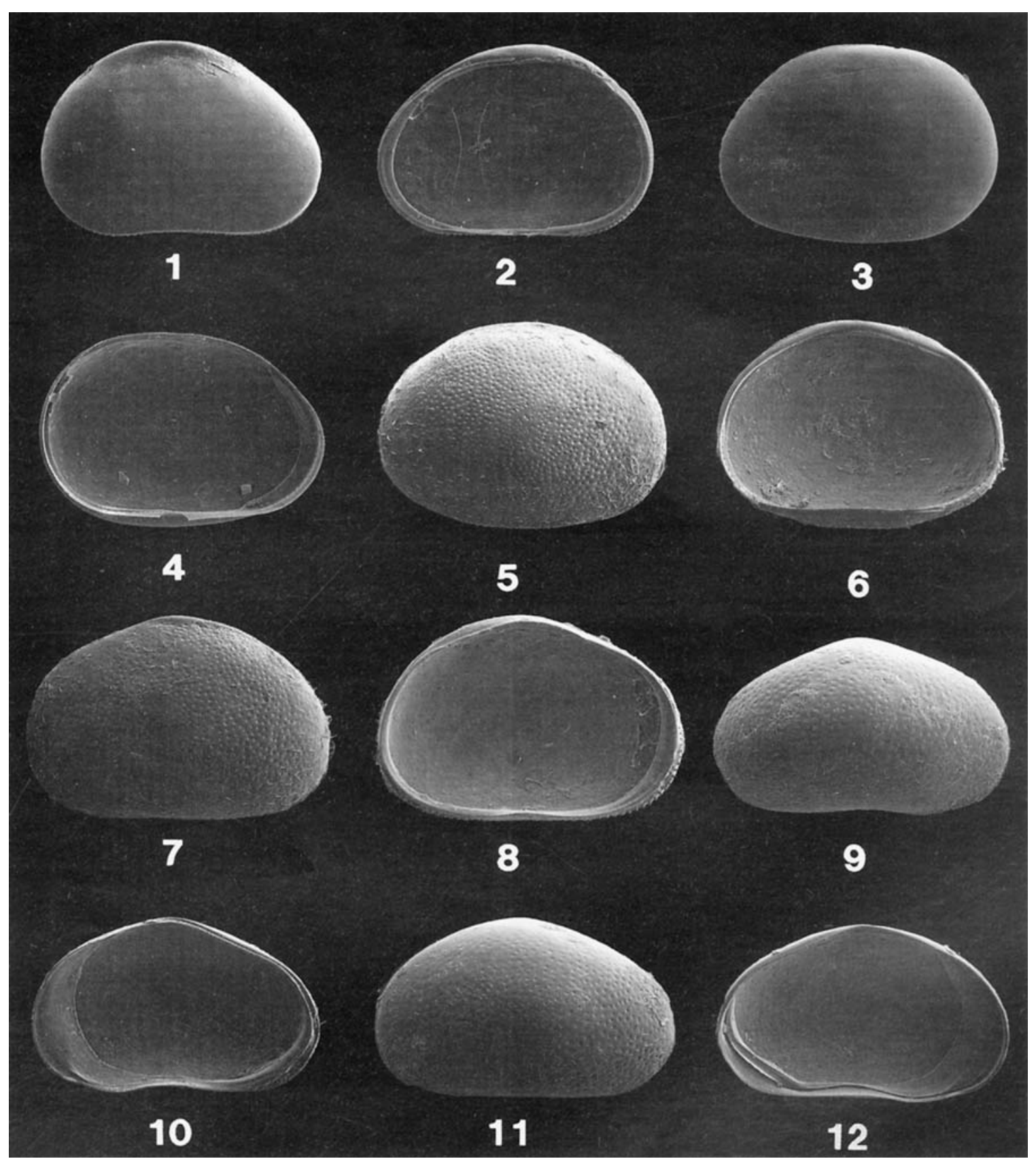

Fig. 4. 1-4: Physocypria deformis Klie, 1940. (×72). 1, external lateral view of right valve (1995.157). 2, Internal lateral view of right valve (1995.158). 3, External lateral view of left valve (1995.157). 4, internal lateral view of left valve (1995.158). All specimens collected from Negril Road Pond. 5-8: Hemicypris pyxidata (Moniez, 1892) ( $\times 46)$. 5, External lateral view of right valve (1995.159). 6, Internal lateral view of right valve (1995.160). 7 , External lateral view of left valve (1995.159). 8, Internal lateral view of left valve (1995.160). All specimens collected from Lake O. 9-12: Cypridopsis viduella Sars, 1895. ( $\times 82)$. 9, External lateral view of right valve (1995.161). 10, internal lateral view of right valve (1995.162). 11, External lateral view of left valve (1995.161). 12, internal lateral view of left valve (1995.162). All specimens collected from Black River Pond. All figured specimens are deposited in the Department of Zoology, Natural History Museum, London: accession numbers are in parentheses.

The pure marls are generally dominated by very large numbers of $C$. brevisaepta; in some cases the assemblages are monospecific, although often there are variable numbers of Darwinula spp. and Candonopsis sp. present. This is consistent with the results of the open-water tows within the Great Pond, which are dominated by $C$. brevisaepta, and confirms the interpretation of the marls as open-water deposits. The organic marls and muds are not dominated by one species, generally containing C. brevisaepta, Darwinula spp. and Candonopsis sp. in varying proportions. The organic muds contain fewer ostracods and the faunas are more diverse than in the deeper-water sediments. C. brevisaepta is usually a minor component of the 
sediments and is absent from many levels. C. ilosvayi and Strandesia spp. are often present, along with Darwinula spp. and Candonopsis sp. This is consistent with the interpretation of the organic muds as deposits of shallower water from the lake-ward fringes of the reed swamp. The peats themselves contain no ostracods. This may be because the reed-swamp with which they were associated was an anoxic environment unsuitable for ostracods, or the result of poor preservation in an acidic substrate. The earthy calcareous muds similarly lack ostracods, other than reworked fragments. These sediments reflect a largely subaerial environment which was also unsuitable for ostracods.

At no level within the core are there substantial numbers of ostracods representing ephemeral conditions, suggesting that the lake has been a permanent feature during the late Quaternary, except for the period when it dried out almost completely, for which there is no ostracod record.

In summary, ostracods have excellent potential to provide information on changing habitats associated with lake-level variations in Wallywash Great Pond.

\section{CONCLUSIONS}

The recent ostracod samples from non-marine habitats in western Jamaica contain several Neotropical elements, together with a number of circum-tropical taxa, and some cosmopolitan species. The occurrence of three species that are extremely rare or previously unreported from the Neotropics possibly reflects the lack of past work in this region. There seems to be a reasonably clear distinction between the small waterbodies, which are subject to large fluctuations, and the relatively large lakes, specifically Wallywash Great Pond and Weston Favel Lake. The former group of waterbodies is dominated by Cypris, Hemicypris and Chlamydotheca; and the latter by Cypretta and Darwinula. Within Wallywash Great Pond, there is some zonation of ostracods within the lake which is largely a reflection of water depth and macrophyte cover.

The modern ostracod faunas described here have several important implications for work on the late Quaternary ostracod faunas of Wallywash Great Pond. They suggest that lake-level variations, together with periods when the lake was temporary or near-temporary, should be apparent in the ostracod fossil record.

\section{ACKNOWLEDGEMENTS}

I thank Koen Martens for ostracod identifications, Peter Henderson for discussions about the fauna, Ian Slipper for taking the SEM photographs and Linda Parry for photographic work. Nan Davies and Philip Hales assisted with ostracod collection and water chemistry determinations. Comments from Koen Martens, David Horne, Huw Griffiths and Angel Baltanás, together with reviews by Mark Williams and an anonymous referee, helped me to make significant improvements to the paper. This work was funded by the Royal Society Overseas Field Research Fund, the Maurice Hill Research Fund, the Percy Sladen Trust, the British Geomorphological Research Group and Kingston University School of Geography.

\section{Manuscript received October 1994 Manuscript accepted June 1995}

\section{REFERENCES}

Broodbakker, N. W. 1982. Amsterdam expeditions to the West Indian Islands, report 20. The Genus Heterocypris (Crustacea, Ostracoda) in the West Indies. Part I: Taxonomic characteristics. Bijdragen tot de Dierkunde, 52: 207-227.

Broodbakker, N. W. 1983a. Amsterdam expeditions to the West Indian Island, report 24. The genus Heterocypris (Crustacea, Ostracoda) in the West Indies. Part II. Carapace length, ecology and zoogeography. Bijdragen tot de Dierkunde, 53: 115-134.

Broodbakker, N. W. 1983b. Amsterdam expeditions to the West Indian Islands, report 25. The genus Hemicypris (Crustacea, Ostracoda) in the West Indies. Bijdragen tot de Dierkunde, 53: 135-157.

Broodbakker, N. W. 1983c. Amsterdam expeditions to the West Indian Islands. Report 34. The subfamily Candoninae (Crustacea, Ostracoda) in the West Indies. Bijdragen tot de Dierkunde, 53; 287-326.

Broodbakker, N. W. 1983d. Amsterdam expeditions to the West Indian Islands, report 35. The genus Strandesia and other Cypricercini (Crustacea, Ostracoda) in the West Indies. Part I. Taxonomy. Bijdragen tot de Dierkunde, 53: 327-368.

Broodbakker, N. W. 1984a. The distribution and zoogeography of freshwater Ostracoda (Crustacea) in the West Indies with emphasis on species inhabiting wells. Bijdragen tot de Dierkunde, 54: 25-50.

Broodbakker, N. W. 1984b. The genus Strandesia and other Cypricercini (Crustacea, Ostracoda) in the West Indies. 2. Carapace length: Ecology and distribution of two Strandesia species. Bijdragen tot de Dierkunde, 54: 1-14.

Broodbakker, N. W. 1984c. The genus Tanycypris (Crustacea, Ostracoda) in the West Indies. Bijdragen tot de Dierkunde, 54: 15-24.

Harrison, A. D. \& Rankin, J. J. 1976. Hydrobiological studies of eastern Lesser Antillean Islands, II St. Vincent: freshwater fauna -- its distribution, tropical river zonation and biogeography. Archiv für Hydrobiologie Supplementband, 54: 275-311.

Herrick, C. L. 1887. Contribution to the fauna of the Gulf of Mexico and the south. List of the fresh-water and marine Crustacea of Alabama, with descriptions of the new species and synoptical keys for identification. Memoirs of the Denison Scientific Association, 1: 1-56.

Holmes, J. A. 1992. Nonmarine ostracods as Quaternary palaeoenvironmental indicators. Progress in Physical Geography, 16: 405431.

Holmes, J. A. in press. A late Quaternary Ostracod record from Wallywash Great Pond, a Jamaican marl lake. Journal of Paleolimnology.

Holmes, J. A., Street-Perrott, F. A., Ivanovich, M. \& Perrott, R. A. 1995. A late Quaternary palaeolimnological record from Jamaica based on trace-element chemistry of ostracod shells. Chemical Geology, 124: 143-160.

Klie, W. 1933. Zoologische Ergebnisse einer Reise nach Bonaire, Curaçao und Aruba im Jahre 1930. No. 5, Süss- und BrackwasserOstracoden von Bonaire, Curaçao und Aruba. Zoologische Jahrbücher, 69: 369-390.

Margalef, R. 1961. La vida en los Charcos de agua dulce de Nueva Esparta (Venezuela). Memoria de la Sociedad de Ciensias Naturales la Salle, 21: 75-110.

Martens, K. \& Behen, F. 1994. A checklist of the recent non-marine ostracods (Crustacea, Ostracoda) from the inland waters of South America and adjacent islands. Travaux Scientifiques du Musee National d'Histoire Naturelle de Luxembourg, 22: 1-81.

Street-Perrott, F. A., Hales, P. E., Perrott, R. A., Fontes, J. C., Switsur, V. R. \& Pearson, A. 1993. Late Quaternary palaeolimnology of a tropical marl lake: Wallywash Great Pond, Jamaica. Journal of Paleolimnology, 9: 3-22.

Tressler, W. L. 1956. Ostracoda from the Bromeliads in Jamaica and Florida. Journal of the Washington Academy of Science, 46: 333-336.

Triebel, E. 1961. Süßwasser-Ostracoden von den Karibischen Inseln: 1. Cypridini. Senckenbergiana Biologica, 42: 51-74.

Triebel, E. 1962. Süßwasser-Ostracoden von den Karibischen Inseln: 2. Xenocypris n.g. Senckenbergiana Biologica, 43: 47-63.

UNDP/FAO 1971. Groundwater surveys in two areas of the interior, Jamaica. Appraisal report of the Pedro Plains, St. Elizabeth. AL:SF/ JAM3 Technical Report 1: 1-192.

van den Bold, W. A. 1958. Distribution of freshwater ostracodes in Trinidad. Micropaleontology, 4: 71-74.

Zans, V. A., Chubb, L. J., Versey, H. R., Williams, J. B., Robinson, E. \& Cook, D. L. 1962. Synopsis of the Geology of Jamaica. Bulletin of the Geological Survey of Jamaica, 4: 1-72. 